\title{
ISSUES IN THE DEVELOPMENT C MULTICHANNEL TACTILE DEVICES FOR HEARING-IMPAIRED CHILDREN AND ADULTS
}

\author{
Rohert S.C. Cozum, Ph.I)., I).Aud., ".t Karyn L. Galvin, B.St., D.Aud., 1.? \\ Julia \%. Saremt, B.S., I).Aud., '.2 Peter J. Blamey, Ph.I)., 1.7 \\ and (indeme M. C.lark, Ph.D., IRACS',?,-1
}

levitl, Pickell, and llomde (1980), in their landmatk monegraph, noted that the history of tactile ald derelopment has beren chatacteriaced be periodic bursts of enthusiasm and rescatch, oflen culminaling in iclentilication of new arenues to be explored lor improving lacile perecention of speech. While several researele groups hare maintamed long-tem interest in tactile reseatrote (Boollmovel. 1985; Oller. Parme. \& Givin, 1980: Simmelers, 1985), there wals a matted increatio itl reports of new multichantuel tacdike devices during dhe lases erevieweel in

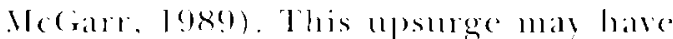
been spureel in part be the rapid incerase world-wide in the number of hearingimpained childeen and adults ming cochlean implants as evervdas commomiontion devices, and the pereceived need for a monstrgical approach 10 assisting learingimpained childeen. Despite this increase in ractile reseatele, no tactile eleviee has yed achieved widespread commereial use by ahe

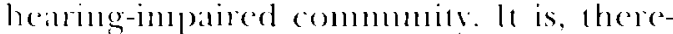
fore, of interest an question why cochlean implants lave been more widely accepted hlant tactite devicess
A primary reason would be the relative speech perception bencefits avaliable to users of either cochlear implants or tactile devices. However, direce comparison of specels perception benclits is difficult, because few hearing-impaired children or aclults have used both types of devices, and it is also difficult to generalize the results of matched group stuclies to the popmlation as a wholde. It would secm logical that stimulattion of aldelitory nerve libres by implanted clectrodes would have a significant advanlage over tactile stimulation of the shin, because it might exploit the normal higherlevel auditory pathways, and in postlinguistically dealened children and adults, the "learned" step from auditory sensations 10 speech comprchension. Studies of psychophessical discrimination in patients using multichannel cochlear implants and multichannel electrotactile devices have shown similar scores for electoode identification and pulse width discrimination tasks with boulu devices (Blaney \& (Cowan, 1992). Speech perception studies in the literature have also reported similar levels of bencefit in supplementation of lipreading from use 
derelopment of speech production skills and language accuisition.

The main clements of the Tïkkle Talter ane an externally wom speech processor stimulator min and an electrode hamelsed (Figure 1). The speech processor is based on hatrdwate used in the Nucleus Mini-22 speede processor, and empless a lormant extraction speech processing strategy, providing cues to fundamental fiesuency $(\mathrm{FO})$, second lormant liequener (F⿻上丨), speech wateform anplitude $(A)$, and high-fiecpuenes spectral components (IIF). This information is comvereed to the usere ats a pattern of clectrical stimuli alelivereel to the skin. which resuls in stimulation of the eligital nerve bundles in the fingers ol the nondominant hand fria eight elecouodes, mounted in pairs in four rings as shomen).

\section{Hearing Levels and CoMMUNICATION Handiciap}

The critical aspects of speech that are important for speech perecption include lhe suprasegmental leatures such ats rhylhm, stress, and intonation; and segmen- tal features such als vencel lormant frequent-

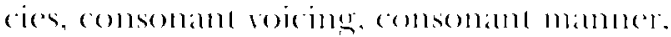
and plater of atriculation. Cines to thene important feallures alle spread acrous the fice-

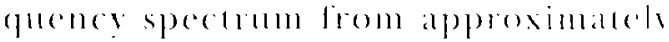

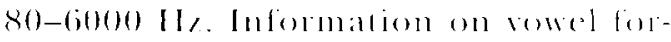
mants and combonam manner and woluters

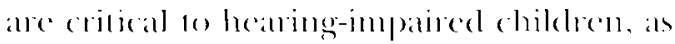
lais information is nol aratable fiom lipreading. The chatarteristic spectral and

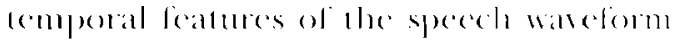
provide mulliple acomstic anes for clistingutishing particulat speceh someds. Mlthough lhese rues are hightr variable. adelitional redumelant coes are present in buglish in

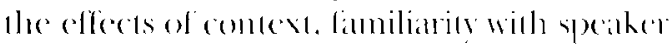
and subject, and the glammatioal and pho netic rules that limit the potential allermattives in phonemes in workts and werds in

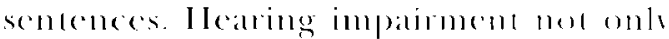

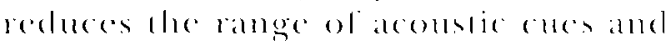
redumblant informatom arablable to the listener, lsul in cases of prelinguistic onset of dealiness. also inumoluces delats in atcenuiling knowledge of vocaloulary and grammart.

The communicalion handicap) of ans

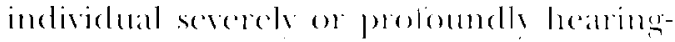
impaired child will vary due to differences

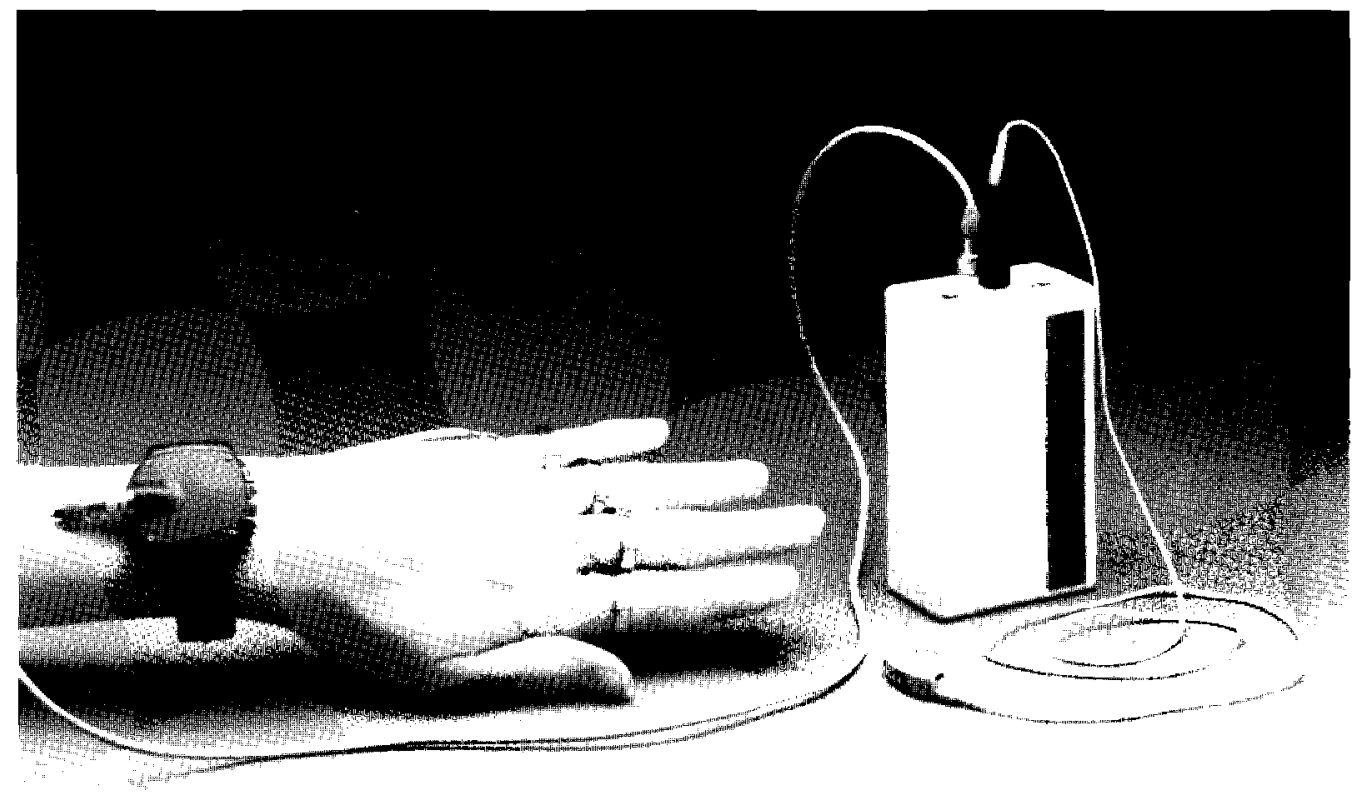

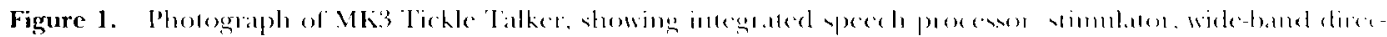




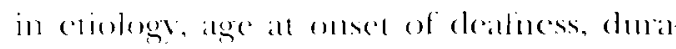
tion of profomed deathess, adided residual hearing thesholds, use of hearing aids, communications swestem emplowed (i.c.. oral, lobal commumicatom, of matual), of the presence of ahtere disabilities. These factors not onle comtribute to delining the commontnication needs of the individual chilel, but alse inlluener potential benelits lor any indivielual from use of any device, thomgh their clloeds on the ability of the chilet on adchle to pereceive speech features acooss the

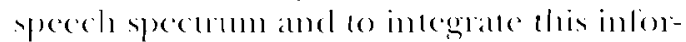
mattion into word recognition ante comples-

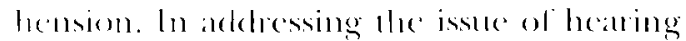
thresholds and communtalation handicap. we alle. dherefore. interested in low much

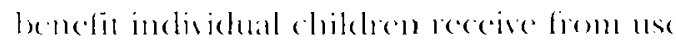
of lipreading and heating aids, and what

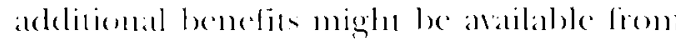

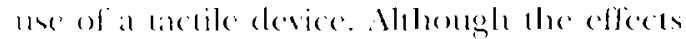

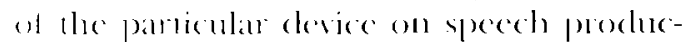
tion and on subsepueme lianguage development of the ehifd alle also importams, hes

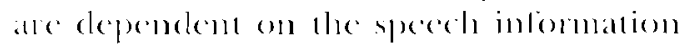

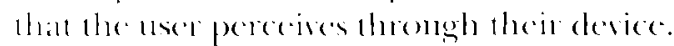

the issues insolved in residual hearing

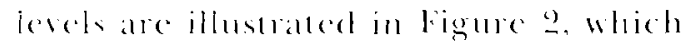

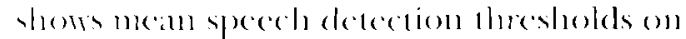

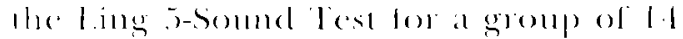

profommelly hearing-impaired childeren using learing aids or the Tickle Talker. Meam bluresholds with hearing aids wore within the nomnal speech spectem up to $1000 \mathrm{fl}$, but chop well below al $2000-4000 \mathrm{H}$ \%. This suggests that the children would be able to access cues to the there vowel sommels with their hearing aids but would be unable to perceive higher frequency consonams. In contarst, thresholds for detection of both lower and higher freguency stimuli were within the nomal speech spectrom when using lhe Tickle Talker. Becaluse highfrepuener edements ane critical to word intelligibility and also comesy importimn grammatical mankers (c.g. /s/ in plurals and possessives), $i t$ is ribal for children to have aceess to this high liecpuency spectual information.

A fumber consideration in assessing residhal heaning leveds and communication handicatp is the proposed function of the device. Most actile devices, including the Tickle Talker, have been designed to provide supplemental information to be used in combinalion with inpul from other modalities. This is in comtrast to cochleatl implants, which in many cascs allow significant understanding of speech using the device alone, operning the possibility of tetephone use, conversations willoul whe need

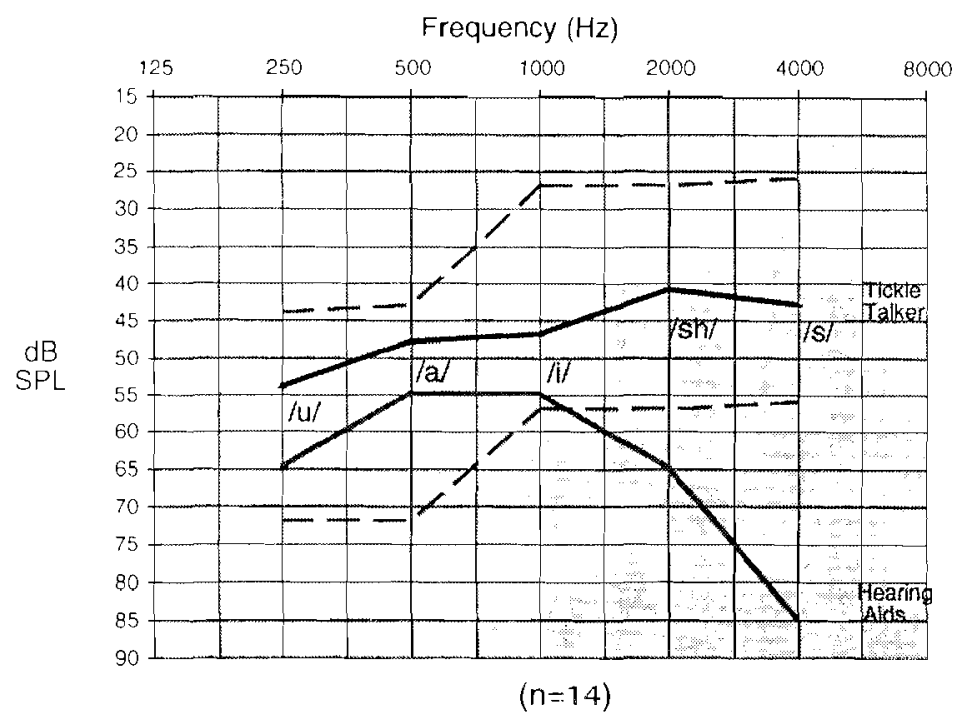

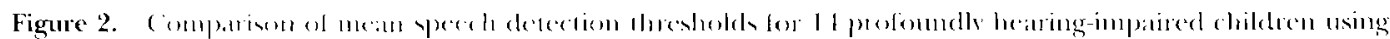

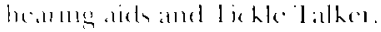


for vistal regard, or commmomicatom in situations of poor visibilits. Figure 3 illustrates how lactile inpul can effectivels supplement information arailable from hearing aids 10 overeome some perceptual limilations. Individual consonant manner discriminat-

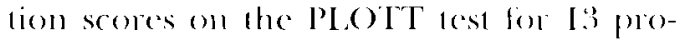
foundly hearing-impaired children using heatring aids alone versits the Tickle Talker plus hearing aids are shown. With hearing aids alone, llece wass a wiele range in score $(40-90 \%)$, consistent with the differing lev(ds of aided residual hearing of individual children. These resules suggest that mant of the ehilderen would be mable to discriminate impertant mamner differeneses in initial and linal consonants using inpout firom hearing alids alome. This information is also mot avalatbe fiom liprealing, because comsoname matuner differences atre homephenous. Ilowever, with added lachile inpoul supplied through the Tiekle Talker. the range of scotes was marowed to $8.5-100 \%$. sugrgesting that all of the childeren were able 10 perecive this contrast by means of lhe supplemental tactual cores. It was evidemt that chilehe'll with the lomest comsontant manner seores using hearing aids alone made the greatess game fiom the atclitional

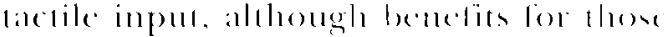
with higher sernes mat hate been limiled bx ceiling cllects on this test.

In the erendals commonutation emirommente severely ame profomedls hearing-

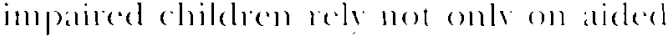
residual hearing, but also on lipreacling w provide coles on speech. Fignare t illustrates how lactile inpon can be uned to provide adclitional cues wo be used in combination with either aided residelal hearing or alded residual hearing and lipmeading. Mean

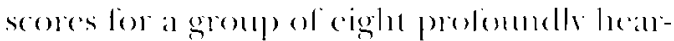
ing-imparied ehildern on six difereme speceh feature discrimination measures were significand lower (p) $<0.05)$ with hearing aicls alome loan mean scores in the

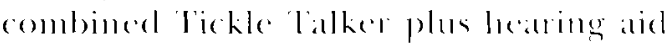
conclition. Figure talso slows mean somes on Phomedicalls Balanced Kinderganten (PBK) Words and on Bambertiomal-Bench (BkB) Semeneses In this case alde abilite of

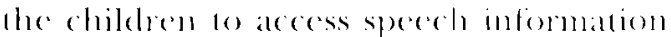
using heaning aids plus lipreadling is compatred with the combinged use of lichle Talker, lipmeacling. and hearing aich. ()il both materials, children soured ignificants

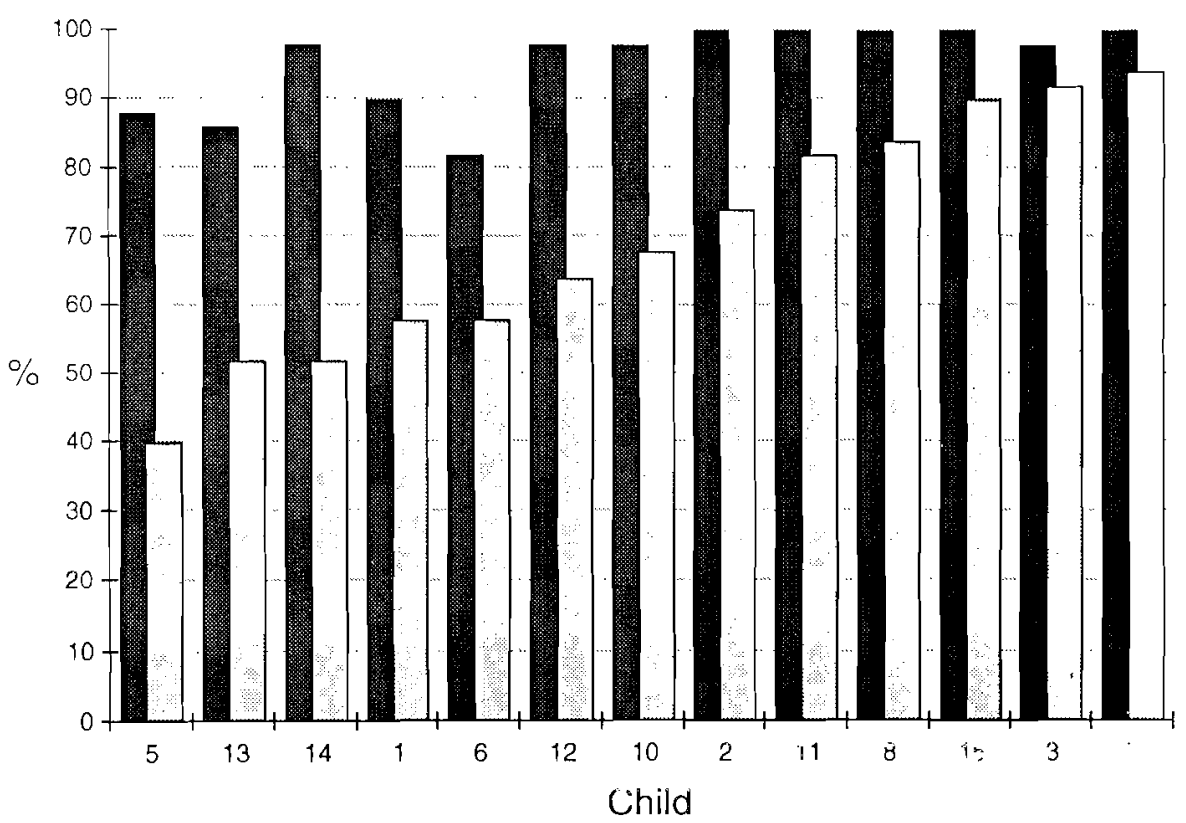

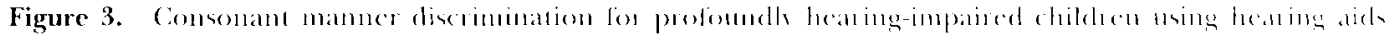




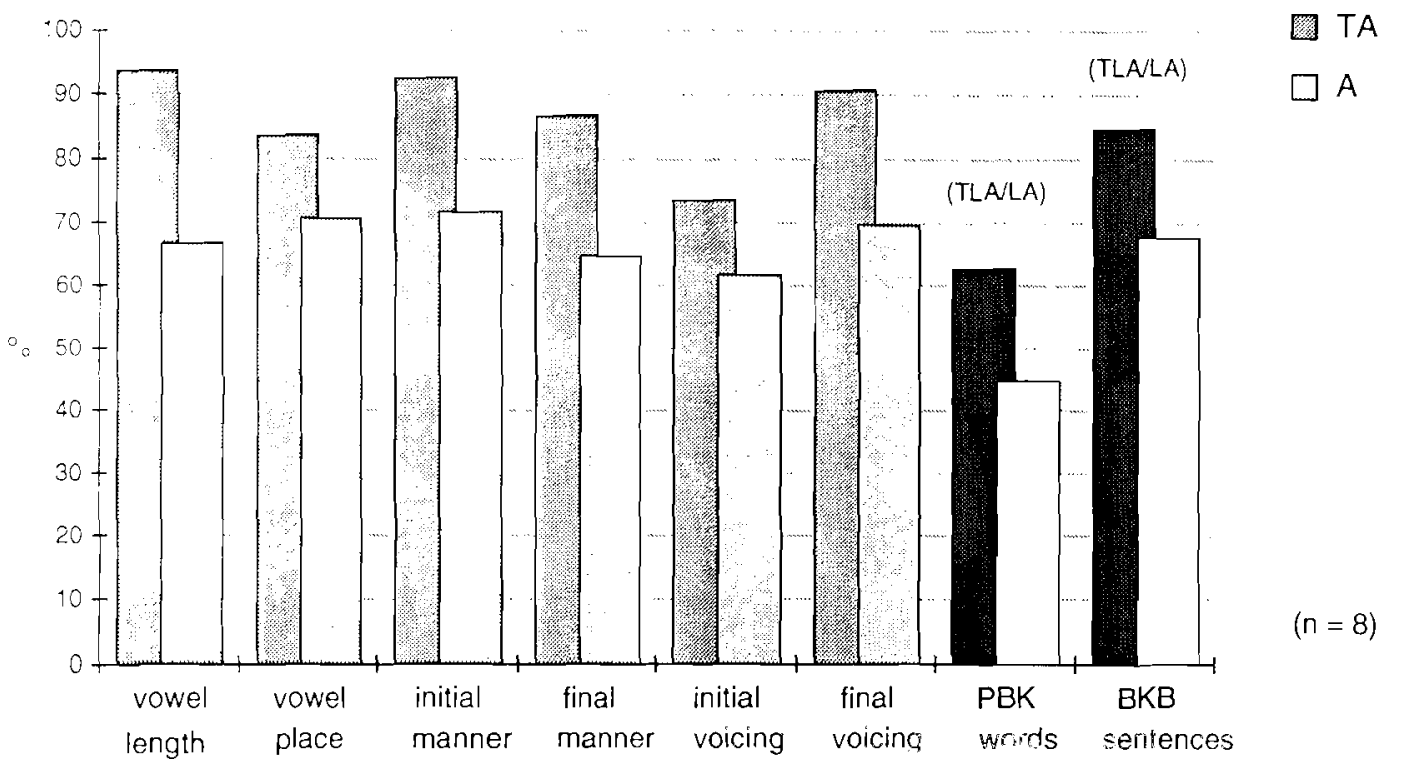

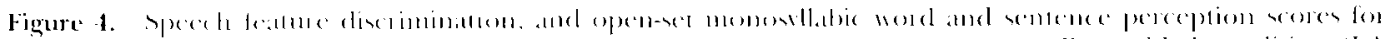

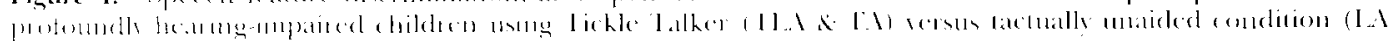
$.4 n 1)$

higher wirh ahe addirional lactile impun (p<

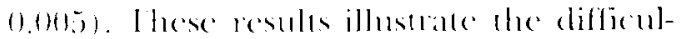

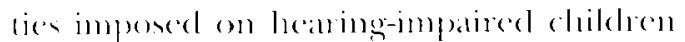

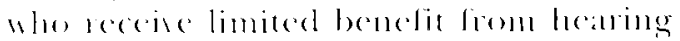

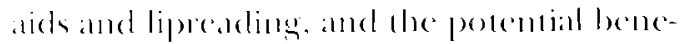
fils arailable from increased acesess to ypecele information lumengh the use of a tatetile deries used in combinalion will liperealing or aided residual hearing.

llating-impatied chilehen often derel(op yecects paltems lhall alle not comsistent with thene of their nomalls-healling peres. imposing and adelitiomal hamdicap lo communication wish he normalls-heating com-

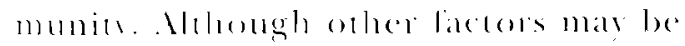
involved. the abilits of children en perecive

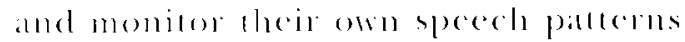

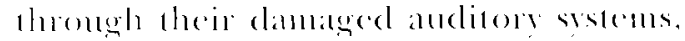
eren with the help of hearing aids, may be we limited. For this reason, all adelitional

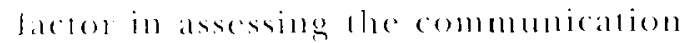
needs of the child in relation to use of taredile devices mats be the role for the tactile device in speedh wellemoniloting and resul-

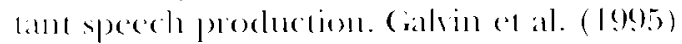
mored improsements in articulation when latrile lecelbatek thromgh the Tiekle 'alker was provided. In this study. the childeren's conversation wale recolded in lwo condi- lions, one with the rhild using lipreading and hearing adels (if linede, and the other with lle Tiekle Talker nsed in adelition ("device-ou"). Figure is illustralles the potential bemelits from use of lactile inpute loo thee of the six childern, whose accurary of arliculation of rowels, cousonants, and phonemes was significamly improved in the device-on comblition.

\section{Sperich Information Provided BY THE DEvice}

The results shown in Figures 1-5 illustate that cues to specilic sperech features important lo vowel and consonam discrimination are alecurately encoded in the latctile oupul of the Tickle Talker, and that these cues all be effectively used by hearingimparied chilelen 10 overeome limitations (o) communication fiom use of hearing aids or lipreading used in isolation. To ensure maximum aceess to speech cues not atvailable liom lipreading or aided residual hearing, a detailed analysis of speech feature encoding was completed (Cowan et al.. l(990), and new encoding strategies bascel on multiple electrode recognition devel- 


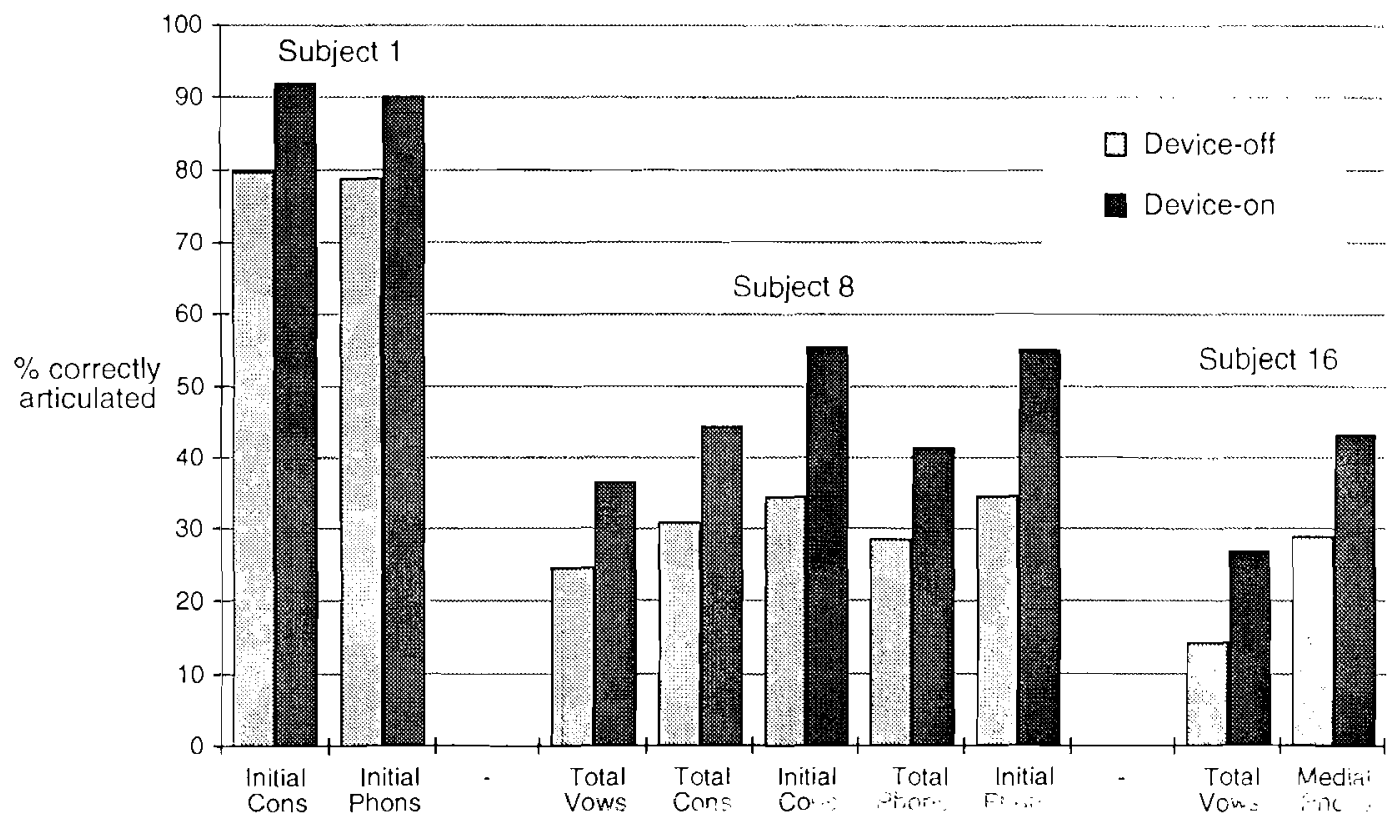

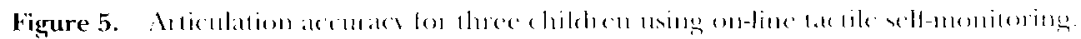

opert ab aldress identified limitatioms (Cowam al al. 1995a). For example, resules

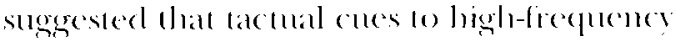
epectral componemes in the voices of chil drem and female speatiens were nol well transmitted by the intial speced processing stralegy emplesere in the Tiekle Tialkere, which encorled only FO, $\mathrm{A}$, and F2. This led 10 elevelopment of he seconderenetation

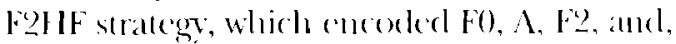
in adclition, a specifir ane bo high-fiectuenes spectarlenergy in the frequener band $1000-8000) 11 \%$. Similaty, analysis ol speech feature discrimination suggesterl that cues to initial comsonant voicing, compered by rhanges in the late of tactile simmation. were not well perededed by adults or childeen using only tactile inpul. Cues to this contrast arc also not arailable form liprealing. T'o overome this limitation, a thirelgencration LF2 encoster strategy was developerl, which provided a specific tactile cole to the soiced voiceless contrast in addition to fo, A, F2, and IIF.

Figure 6 illustrates the affectiveness of this revelopment program in adelessing the communication necels of users be ladually encoding addilional specele cous 1100 seores for discrimination of speech falmen

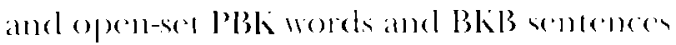

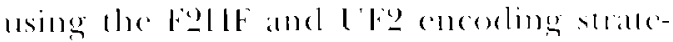
gies are shown lore a small group of pro-

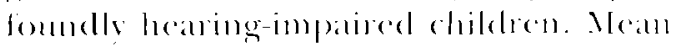

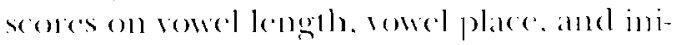

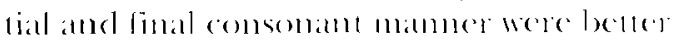

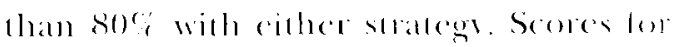
initial and final comsonam voicing were. howerer, significantly implosed $(p)<0.05)$

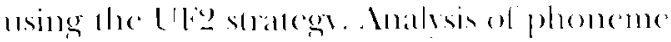
discrimination slggested that the observed signilisant improsement bown wilh the

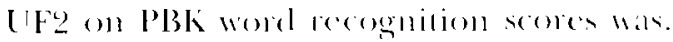
in face, alue to imperesed pereeption of intlial and linal comsomant voicing. lohese resulls steggest thall specele pereception bencelits for the inclividual chilel mat be increased by providing specilic speech loat ture informalion that is nen acesesible through hipereatlong and or airled residaral hearing.

\section{Cosmetic: Design, Risks, AND Ease of Device Use:}

Although we hatre stressed the imperttance ol proveling a lactile signal to speced 


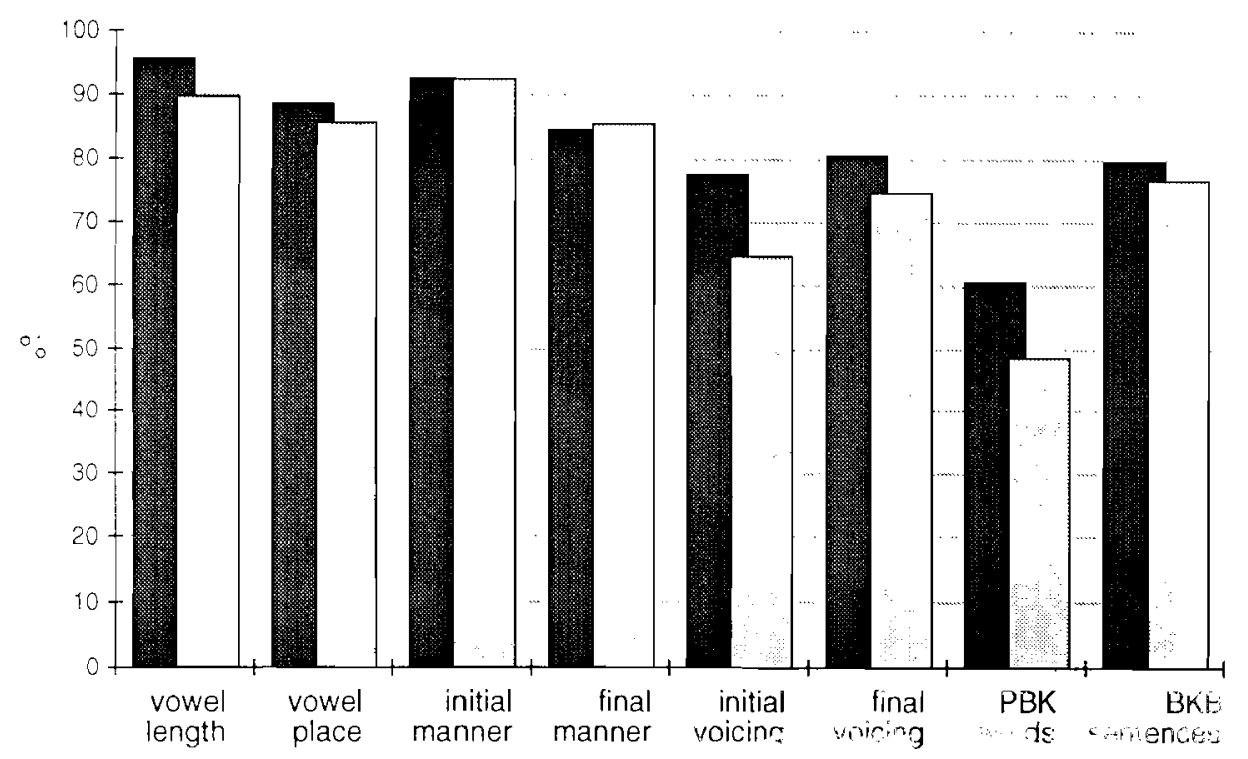

$(x)=4$

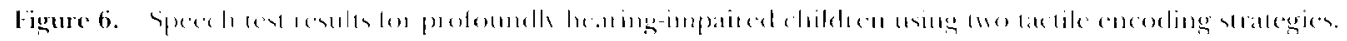

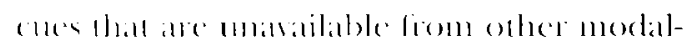

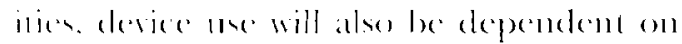

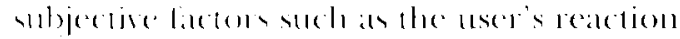

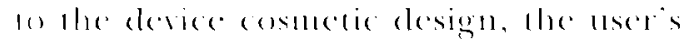

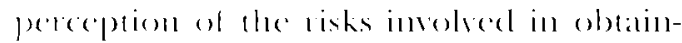

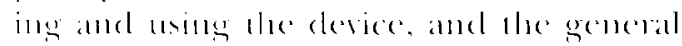
rebiabilits and ease of dails use of the patrtie-

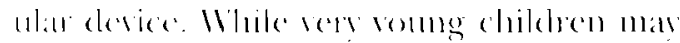

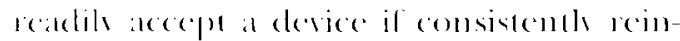
forced h paremes and porelessiomals, is is

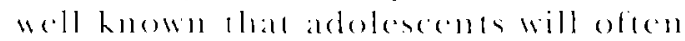

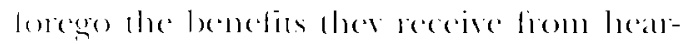
ing alde ol cochleat implathls in order lo

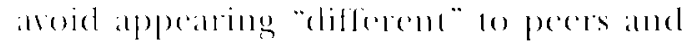

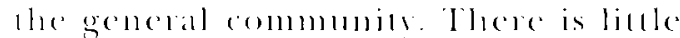

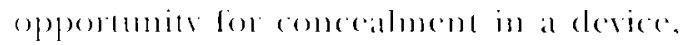

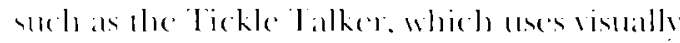

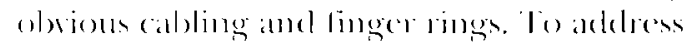

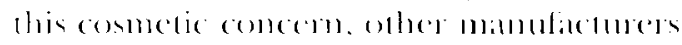
al lactile devices halve opoted lo posiciom

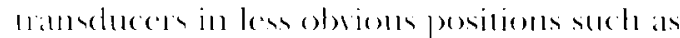

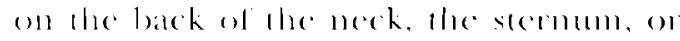
the inside ol the wist. I major disadran-

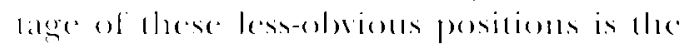

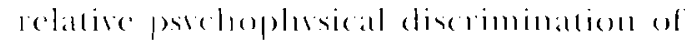

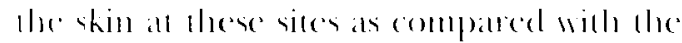
higher tatetmal semsilivite of the fingers and

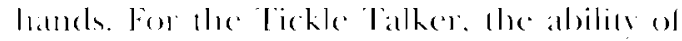

momainded smbjeces to recognize electrode

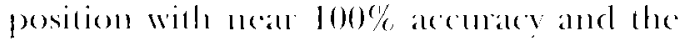
polemtal gaims firom the greales lactual sellsilivily and langer cerebral reporesentation area lor the hand were judged to outweigh

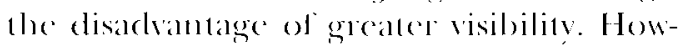
crer, a signilicant research focts remains the develepment of an improved Tickle Talker electrode hamdser, which will also be cosmetically less olsioms and mome acceptable lo mess.

The potemial risks associalled will the strgical procerlume are an obsoms issue llatl must be comsidered in the decisione ol pallcols, childerll, or adolls lo procecel will eochlan implambatom. With implatus, Ihe

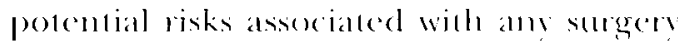
muse be balatuced against ale perecived

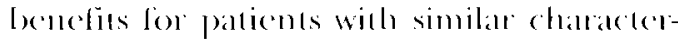
istics (i.c., localing loss, duallom ol deallness. colobogr, cer. and the llack recoted regarding complications for lae particulat implatne system lo be msed. 1)evice saledy isstes have not, in general, been pereciver fo be of such critical importance in lac decision ol parents and childeen lo use tatile devices. The development program

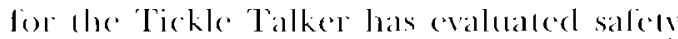


considerations in the electrical design ol the device and the safets of the stimulus paradigm for long-term use (cowan al al.. 1992). Evaluation of the stimulus wareform. speceh processor/stimulator circuitry, and rectrode handsed design showed that polential risks arising fiom the electrolactile mature of the device design have berell adelressed. The use of biphasic constant current pulses, proven biocompatible matcrials, and backup current outpun limitation circtutry eusure that the elevice is electricalls safe. Long-term coulnations of kinestheric sensitivity, vascular studies of hand and hinger blood dlow, and nemrological caluat tions of the effece of the electrical stimmlus on EEG recordings hawe found no significant effects of device use on local dissuce. peripheral nervous system function, or cental nervous sistem activity that might limil long-term use of the deviece Demomstrated safety for any particular device is a critical tactor in reassuring pallents, childerell, and pror fessionals in their decision to use ane tactile device als a long-term communtation aid.

Reliability and ease of device use are also lactors that can affeet the decision of users and professionals reganding use of a device. For cxample, the intial designs of the electrode handse in the Tickle Talker were not robust, and recpuired lrequent changing of electrodes in the ficla by professionals and parents. This also resulted in childern receiving an inconsistent signal. and al tines missing the latede cues important for multimodal speech perceptiont. Tlue initial speced processor/stimulator was also susceptible to RF interference, and was houser in two independent boxes, each of which reguired sepalate batteries. To overcomc these difliculties, ongoing onginecring development is locused on miniaturising the speech processor/stimblature (10) a small simgle unit), reducing the power reguirenents (allowing for 24 hours of use on a single rechargeable $A A$ battery), and designing a robust electrode houndsed, which is also cass, quick, and cheap to replace if required by older children, parents, or professionals in lle licld.

An additional issue is the use of the late- aids and lipreatling. Fon some children. lhi may inwolve use of hearing atels. the lichle lalker, and a radio lieguender (RT) unir. The number of microphones insolved. and the combined weight and cabling inwohed can be a delinite negative factor in terms of case ol use. Device develepument must

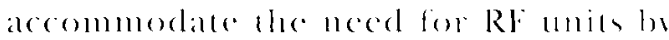
heatring-impaired rhilderen and if powible develop means of using wireless tramsmission or joime micophone access. Programming of the device is a fiuther issue lo be comsidened

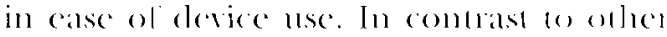
simpler single-chaunel and muldichammel tactile devices, the Tickle Talker uses diginal

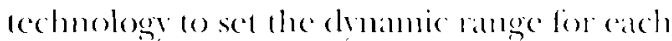
clectrode independentle and also hats the potential 10 implement a rarieds of speesh processing stratregies sperilicalls taibued on the communication meeds of indlividual chitdren. Mhile this is a signilicant arlsoulage in terms of maximising speech perecentom benclists it also recpuires ind lividhal programming of the device, which is an additional inconere

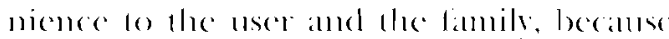
visits to the dinie are repuinced. The derelop-

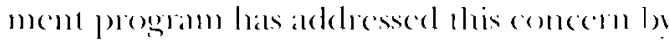
dercloping sofware and an interfice that can be implemented on a potalte le : note-

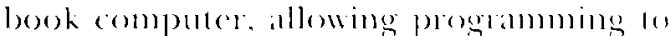
be ellicienty comducted in the school on homer 'mvironment.

\section{USER MOTINATION AND THE Management Prograll}

The motivation of ans hearingimpained child wo use a particular devior is critical not only to the iv crendate use. but also lo blecie inwolvenent and participation in effective habilitations. This is a rer subjeclive lateror, which is related to the usere commmmication necels. For example. deat-

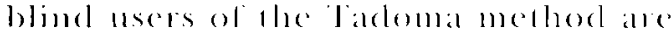

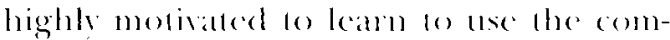
munication method, despite the dillicultien imposed be lone need for close phesical conlace wilh speakers, becallse blece hatre been few pratioal allematives arailable. In the case of cochlear implants. patrent and uscess both adults and childrem, mat be 
and discriminalded be users. In plamuing

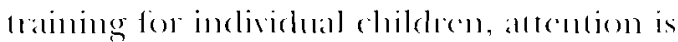
griern to these resules in the chesice and oreler of tasks, with a hierarchical scries of lasks omplaasizing maining of perception in romming spech being emploved. Particulan atlemion is given to the sperilie pereceptual uecels of the chitel, and moniloting of the molivalion and comsisteme! of device use. Regular cvaluations are allministered 10 monitor progress and speceh pereception? production benedits. Experience bas shown that extensive latining with dhe lickle Talker is neerled to maximize speech perrepeion benelïs. Basic phonchere discriminations can be marke using the lactile signal without tranimg: howerer, his does not necessatrity gencralize to pereception of words and semtences withoul periogls of intensive deatining over a minimum (b-month period. Training is more eflective when implemented on a daily bisis, and the management/habilitation program must insolve the parents and teaching protessionals if suceses is 10 be eptimized. Cument reseated

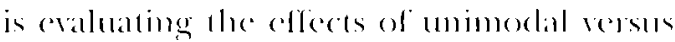
bimostal taining on both integration of tatelike inpul, and tactile-alone perception. These stuclies are vilal oo iclemilfing ke ckements in lactual speech pereeplion, and optimizing tactile dataning programs for use with inclividual derices.

\section{SUMMARY}

We have elisenserel the influenee of a number of individual fictors in lhe suceess lul use of tardile derices. l'actile derices. such as lace Tiekle l'alker, hase been primarily developed to provide adrlitional speech information ab be used in combinattion will speechearling, and in some cases aided resichlat hearing, adderessing 1 he patrdicular inclividual's speech pereception and communication needs. Eablations have

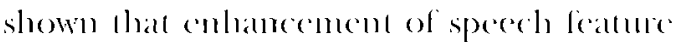
discriminattion wille the elevier mats oceur immediately on fitting, but cffective integratlion of lactually encoded speech leature cues into combined-modialits speech per-

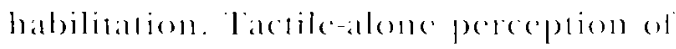

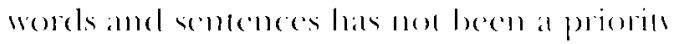

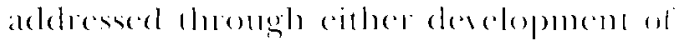

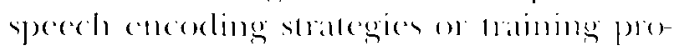
grams. In contrast, cochleat implants halle berens shown to provicle signilieant specets information lo these pallemes whe recedise

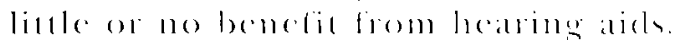
lucreasingle fle decumented abilis of

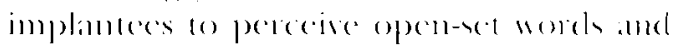
semlences in the implantlatone condition

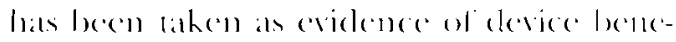
lit, with the degree of wuplementation of obluer semsom modalities such als liprealing of secontalar import. The application of the

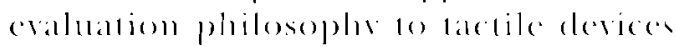

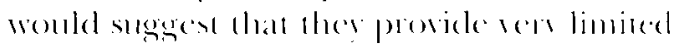

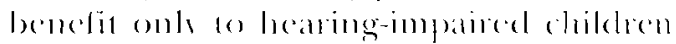
a idlults.

The impoltance of hlow issuce is illusdated in lighore 7 , which shom ypeech perceplion results on plis worels lor three congenitalle deal adoleseconts. ealeh ol whom were initialls lïted with alac lichle lalker, and were subsecpuents implanted with the Nucleus multichameled cochleat

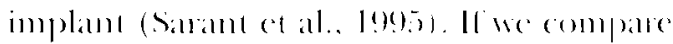

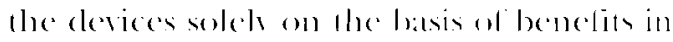
supplementing lipmealing and arded resiet-

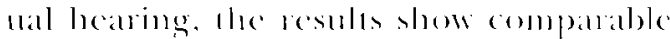

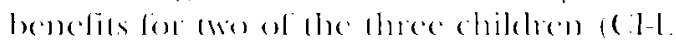

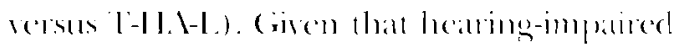

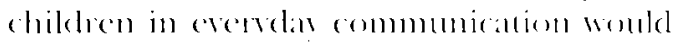
use all arailable yecerb impur (i.c... lhe combiocel modality condition), it might be

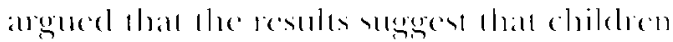
woulde de equalls wedl with either of the mo

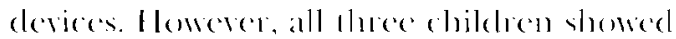
some molerstanding of speceh through

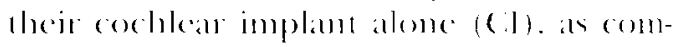
patred with only one child showing wers limited understanding of open-sed epeecte

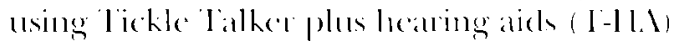
or hearing abls alone (II.J). This devicealone pesception in the case of corbleate implints provides a disind communticalion aclemblage, because il allows comersation

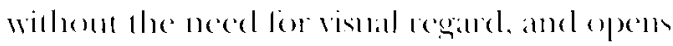
the posibility of telephente comersition.

lach ol these thece childen were experienced users of the Tichle Talker, and

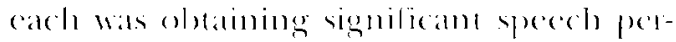




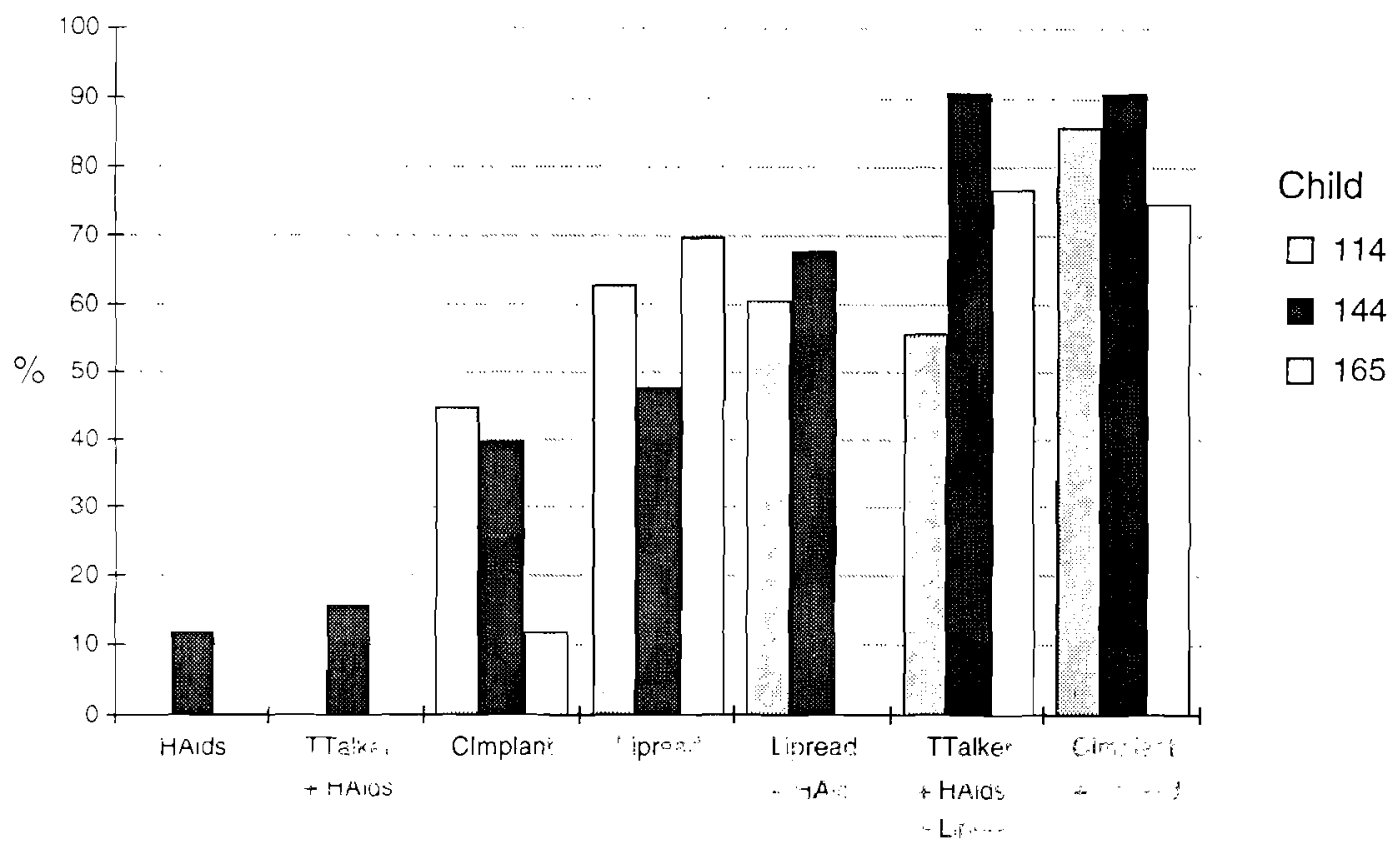

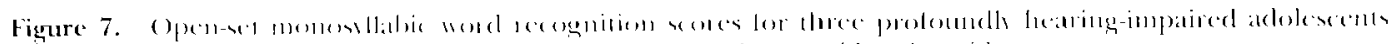

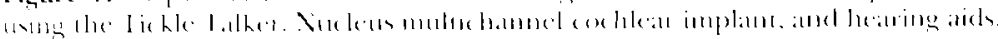

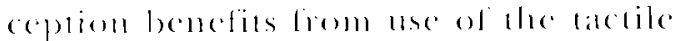

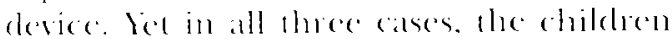
and parrents elecieled lo presecere with eochleat implamlation, despile the risks

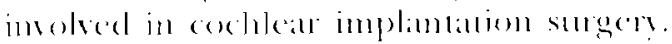

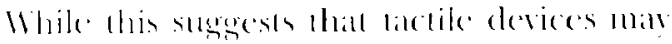

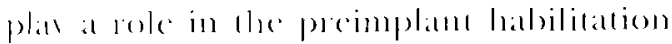

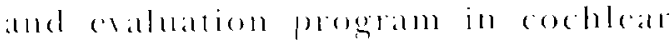

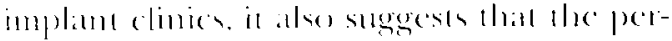

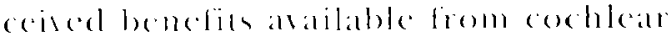

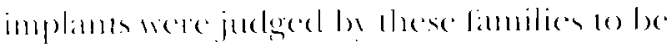

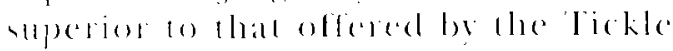
lalkere. Inlemmal combersatems with the

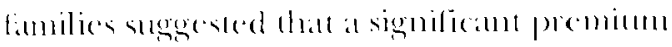

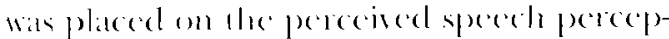
lion bencfils atsilable form cochloar

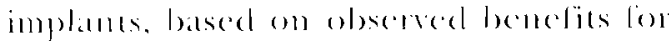

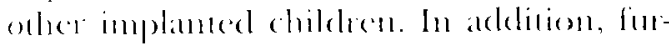
there comsiderations were lhe cosmetic istaes, reliabilit, atud aase of use of the dif-

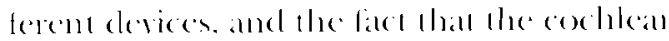
moplantr wats a commenedial clevice in comtrast

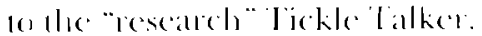

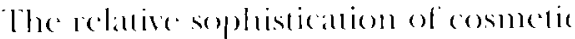

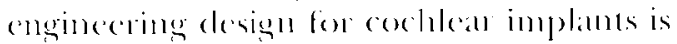

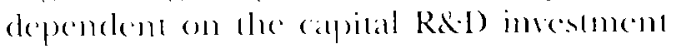
of companies cleveloping commmercial cochleat implant sysems lor use in mocelical clinical palclice Again, in comtrast. only one l s.s. company is a major commonclcial mammbander of lactile devices, while most rescatroh organisations developing moliphe chanmel latelile deveces have focused limiled resontreses primarily on speech perecplion benclits. To achieve mone widesporal use. tactile devices most adelecescostmetic issues, lex rolutsuly designed, reliable, and cast (1) $11 \mathrm{se}$.

An additional issue in motivating the decision to procecel with a cochleat implant insteatel of a lactile device maty be blue funding of devices. Al present, cochleats implant stsems in Austablia are dislly funded by public hospital services or privale health instreance. Prialle heallo coverage is also arailable lor cochleate implants in the Lniled Stales and in some Eulopean commluics. In contmase. lew provisions are made lor lionding of laceile deviers worlel-wide (allhomgh a limited number ol mulachanmed taclile devices atre provided in Australias). Developers of laterile devices must, therefere, comsider costs when making decisions on hardware or specele processing to be buile into the 
tactile deriecs. If laterile derices caln be kept relatively simple, resultant production and market costs should be much less than for cochleat intulants, which mas be an imporlatut factor in clecisions of health progtants regarding allocation of resources for the group of pattients suibable for lactile devices.

In stmmary, given the more limited benefits to speech pereption, the itt-general lower tevel of cosmetic sophistication in the clesign and the necessity for extensive and intensive thaning, it is not supprising that lactile derices have not vet achieved a similat level of user acceplance as that lon cochleat implants. It is crident from lhe results presented that the multichannel Tickle Tilther can provide signilisant bencfïts to speceh perception and speerh prom daction. Howerer, potential camdidales, who are primarily ahose severely or profoundly hearing-impaired adults and children who do not proceed with cochleal implantalion for medical, amdiological, financial, or other reasons, must still be convinced that the issues of cosmetic visibilits, reliability, and ease of use hawe been successfully addersecel. Potential commonicalion benefits and cost facters must also be sufficientle positive to motialle them to patllicipate in the long-term tratining necessats 10 suceessfully use the tactile deviere. The need to assess each patient's communicat lion and to individually lator the litedile

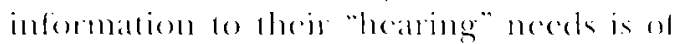

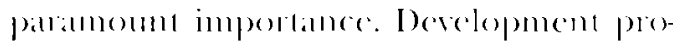
grams for latetile devices must atlempt lo find bener medhods of tacmatly encoding

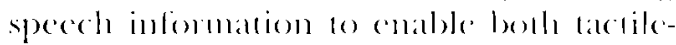
alone perecprom of speech and beter supplementation ol lipereading and aided resideal hearing. Fhere iestes must be

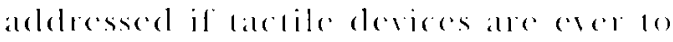

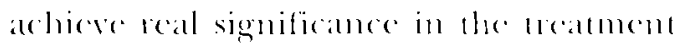
and management of serere and profound lecaring impairnucher.

\section{AckNowlidogirists}

Support for the Tiekte Talker derelopement has becen provided by the commonwealle of Austratia through the catablish-

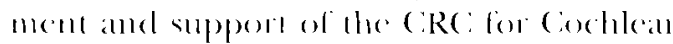
Implant, speech and Ileaning Rescalleh. and from llac Department of Industa. Techmologe and commerese the National Ileallh and Medical Resealleh commeil of

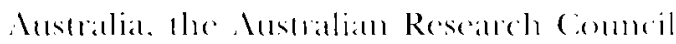
through the award of the Ituman fommumication Rescarch cientre coochlear Pts Limired, He coorge Hicks Fomblation and the Lan Polter Foundation. Tirke Talker is a registered l's. matemate of the l niversity of Melbourne.

\section{REFERENCES}

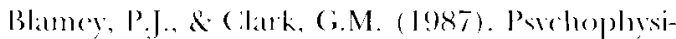
al studies rederant oo the design of a digitial electrotaldite speech processor. Joumal of the Aroustical Society of Lmeticto 82, 116-18.7.

Blanc'y, P'J., \& Cowan, R.S.C. (1992). The porential benclit and costeffectiveness of lactile devices in comparison with oochlear implants. In I.R. Summors (Fol.). Tatetile aids for lhe bearing impaime (pp. 187-217). Iondon: Whour Publishers.

Boolhoved, A. (1985). A wealable late tile intemat lion clisplay for the deall. HeFt: Tramsartions in Acomsics Spered Processing, 33.111-117.

Brooks. P.1.., Frost, B.J., Mason, K.l. \& Gibsom,

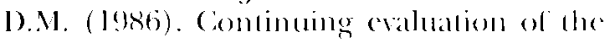

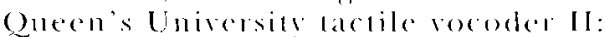
flemilication of open sentences and llacking narrative. fonrmal of Rehabilitalion

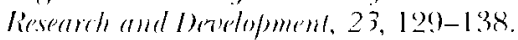

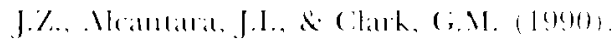

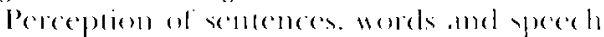

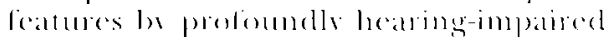

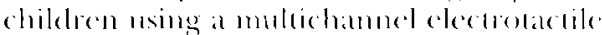

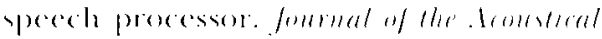

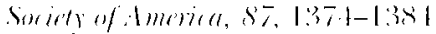

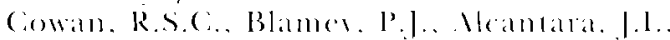
Blombers, P.... Ilophins, I.]. Whitfurd.

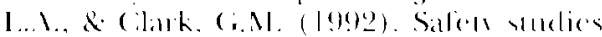

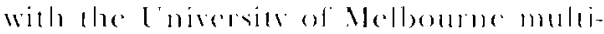

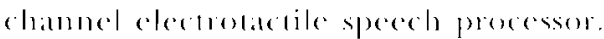
fourmal of Rebabilitalian liesearth and berelopmeml. 29.35-59.

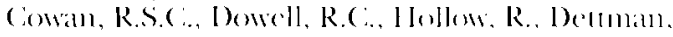
S.J. Raller, (;., Barker, \&.J. Sillam, J.\%.

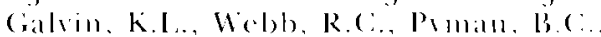

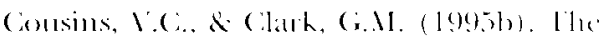
pogress of childen cosing 1 he multichammel

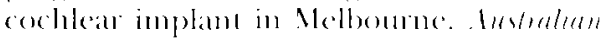

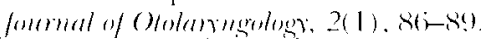




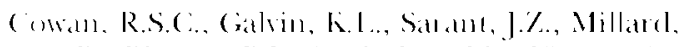
R.. Btamer, P.J.. de (lath, (i.M. (1995a). An impored clectrotadite ypeceh processor:

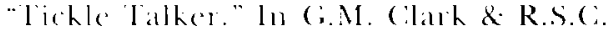

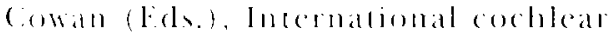

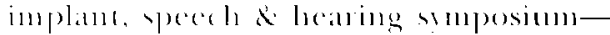
Melbomone, legle Ammal, of Olologr,

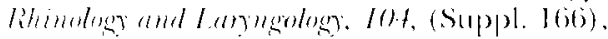
$1.51-150$.

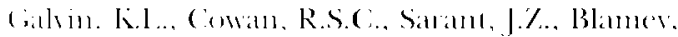

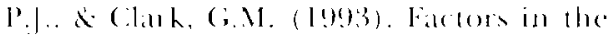

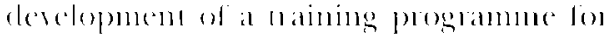

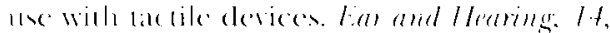
$11,4-127$.

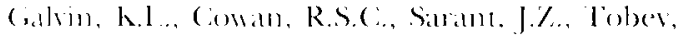
li... Blamer, l'J., \& (dark, C.M. (1995) Gliculation self-monitoring uning an

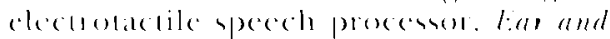

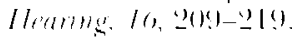

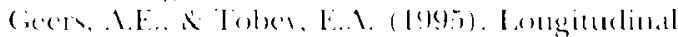
compalion of the bencelits at enchleat implams and laterile aids in a combobled

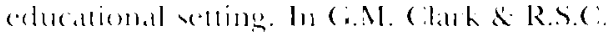

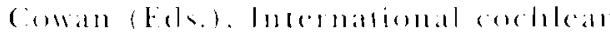
Implant. specels 8 lacaling

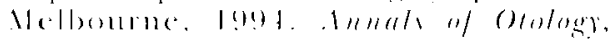

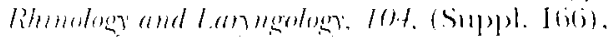
$30-3-3.909$

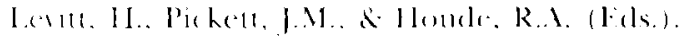

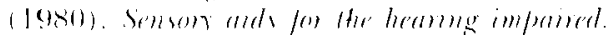
Xiw lork: IFEF l'acss.

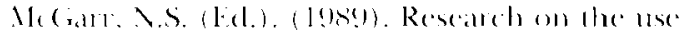
of semon aid fos hearing-impated peo-

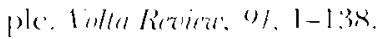

()ller. [).K. Panne, S.1.. \& (jallin, M.]. (1980). lactual seech perception br minimally
Wained cleat subjects. foumal of Sperth and

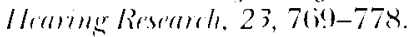

()sbeger, M.J., Roblbins, N.M., Miyamoto, R.T., Berre, S.W., Mures, W.A., Kessler, K.S., Pope. M.1. (1996). Specolo perceptiona abililies of rhildern with cochloin implints, tate-

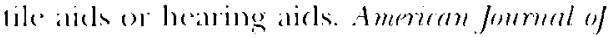
Ololegr. Suphlemem, 12, 105-115.

Sanam, I.\% Cowan, R.S.(.., Blamey, P.l., Galvin, K.I., \& Clark, (;.M. (1999), Within-subject comparison ol speech perception benedits with a muliphle-clammel cochleat implant and tacdite device. In G.M. Clath \& R.S.C. Cowan (Fels) Interlational cochleat implant, speech \& heating symposiumMelboume, 1994. Annels of Otology, fihimology and Larmgologe, 104, (Suppl. 166), 339)-341.

Samuders, F. (1985). Tartiom logot alectrocutaneous rocoder. Concond, CiA: Tasticon Comporation.

Shinner, M.W., Ciark, G.M., Whitforel, L.A., Seligman, P.M., Staller, S.J., Shipp, l).B. Slablop, J.k., Everingham, C., Menapace, C.M., Arude, P.l.., Antoguelli, T', Brimacombe, J.A., Pijl, S., Daniels, P., Gorge, C.R., MCDermolt, H.J., \& Beiter, A.L. (le94). Evaluation of a new spectmal peat coding strategy for the Vucleas 20 chammel cochlear implant system. Ameriean fournal of Obleng, /5(Suppl. 2) , 15-27.

Woisenberger, J.M., Broadstone, S.P., \& Kumaspres, l. (1991). Relative performature of single-chammel and multichammel tatedile aids for speech discrimination. fournal of

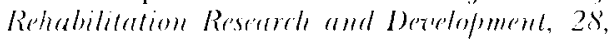
$45-56$. 


\section{University Library}

\section{- M M N E R VA A gateway to Melbourne's research publications}

Minerva Access is the Institutional Repository of The University of Melbourne

Author/s:

Cowan, Robert S. C.;Galvin, Karyn L.;Sarant, Julia Z.;Blamey, Peter J.;Clark, Graeme M.

Title:

Issues in the development of multichannel tactile devices for hearing-impaired children and adults

Date:

1995

Citation:

Cowan, R. S. C., Galvin, K. L., Sarant, J. Z., Blamey, P. J., \& Clark, G. M. (1995). Issues in the development of multichannel tactile devices for hearing-impaired children and adults. Seminars in Hearing, November, 16(4), 356-369.

Persistent Link:

http://hdl.handle.net/11343/27461 